\title{
Technological Competition, Innovation Motive and Corporate Social Responsibility: Evidence from Top Managers of European SMEs
}

\author{
Johan Graafland ${ }^{1}\left[\right.$. Niels Noorderhaven ${ }^{2}$
}

Published online: 31 October 2019

(c) The Author(s) 2019

\begin{abstract}
Various motives have been proposed for firms to engage in corporate social responsibility (CSR), but no attention has been paid to innovation as a motive to engage in CSR. In this paper we explore the role of this motive and hypothesize that it is particularly important for companies facing intensive technological competition. We find support for this in a sample of 2579 top managers of small and medium sized enterprises from 12 European countries. The innovation motive mediates the relationship between technological competition and CSR and is the most (second most) important motive for environmental and social CSR, respectively.
\end{abstract}

Keywords Corporate social responsibility · Innovation motivation · SMEs · Technological competition

JEL Classification L1 $\cdot$ M14

\section{Introduction}

In light of the salience of social and environmental challenges in society, over the last quarter century several studies have explored motives for corporate social responsibility (CSR) (Muller and Kolk 2010; Aguilera et al. 2007; Bansal and Roth 2000). Whereas most studies explored engagement among large companies, other studies focus specifically on CSR motives of small and medium sized enterprises

Johan Graafland

J.J.Graafland@uvt.nl

Niels Noorderhaven

n.g.noorderhaven@tilburguniversity.edu

1 Department of Economics, Tilburg Sustainability Center/CentER, Tilburg University, Room K310, Warandelaan 2, 5000 LE Tilburg, The Netherlands

2 Department of Management, CentER, Tilburg University, Room K838, Warandelaan 2, 5000 LE Tilburg, The Netherlands 
(SMEs). For example, using a sample of 102 SMEs from a variety of industrial sectors in the UK, Brammer et al. (2012) distinguished six strategic motives: long-term financial benefits; short-term financial benefits; legislative compliance; customer pressure; supplier initiative; and market position and market share. These authors found that managers of both small and medium sized enterprises rate legislative compliance highest, but also agree that long-term financial benefits and customer pressures drive their CSR.

However, previous research into the motives of CSR has paid no attention to another likely motive to act in socially responsible ways: innovation. There is evidence that CSR may be of strategic value for companies because it can stimulate innovation (Wagner 2007; Hull and Rothenberg 2008; MacGregor and Fontrodana 2008; Padgett and Galan 2009; Ziegler and Nogareda 2009; Bocquet et al. 2011; Jamali et al. 2011; Lioui and Sharma 2012; Luo and Du 2015; Flammer and Kacperczyk 2016). However, while the abovementioned studies establish a statistical link between CSR and innovation, this does not mean that managers of firms engage in CSR because of the expected positive impact on the innovativeness of their company.

In this study we explore whether managers invest in CSR because they expect this to have a positive impact on innovation (next to other outcomes). We base our reasoning on expectancy theory (Vroom 1964), which posits that the motivation for an action is the product of the belief that the action will lead to a certain outcome and the value of that outcome to the decision maker. Building on this we theorize that managers (next to other motives) choose to invest in CSR because they believe that this leads to innovation, and they see innovation as important to their firm.

We focus on top managers of SMEs because while top managers generally have an important influence on strategic decisions (Hambrick and Mason 1984), this is particularly the case in SMEs (Laufs et al. 2016). Moreover, SMEs make up $90 \%$ of businesses worldwide and account for 50-60\% of employment (Jamali et al. 2009), hence it is evidently important to know if the top managers of SMEs also perceive a CSR-innovation link. SMEs are often considered to have distinctive characteristics (Battisti and Perry 2011). Lack of managerial time, finances, and skills and knowledge are commonly identified as constraints to CSR for SMEs (Welford and Frost 2006), and these factors are also a barrier to innovation (Hewitt-Dundas 2006). However, SMEs are also more flexible and adaptable and can therefore more rapidly take advantage of new niche markets that incorporate social and environmental benefits. SMEs may also be more creative and innovative and innovation is therefore a viable source of competitiveness for SMEs (Jenkins 2009). Hence it is an open question whether the innovation motive plays a role in CSR decisions of SMEs. Of the studies cited above, only MacGregor and Fontrodana (2008) looked at the link between CSR and innovation for SMEs, but their explorative research is limited to 60 firms and does not allow them to test hypotheses.

Business strategies and top managers' motivations, however, do not develop in a vacuum but are influenced by the external environment of companies. The role of technological competition in driving CSR has remained underexposed in the literature. Building on institutional literature (Aguilera et al. 2007; Campbell 2007; Brown et al. 2010), we conjecture that top managers' motivation to engage in CSR 


\begin{tabular}{|c|c|c|c|}
\hline $\begin{array}{c}\text { Intensity of technological } \\
\text { competition }\end{array}$ & $\mathrm{H} 2$ & $\begin{array}{c}\text { Innovation motivation } \\
\text { of top manager to CSR }\end{array}$ & $\mathrm{H} 1$ \\
\cline { 1 - 1 }
\end{tabular}

Fig. 1 Conceptual model

depends on the market environment in which the company operates. Top managers of companies operating in a market with strong technological competition will attach a higher value to innovation. As the value of the outcome of an action increases the motivation for this action, expectancy theory predicts that technological competition increases the innovation motive of CSR. If the innovation motive drives CSR, the strength of the innovation motive for CSR of top managers will mediate the positive effect of technological competition on CSR.

Our study makes three major contributions to the literature. First, this paper theorizes the importance of innovation as a motive for corporate social responsibility of SMEs. Second, we develop a conceptual framework linking the innovation motive to the competitive environment of the company and postulate a mediating role of the innovation motivation of top managers in the relationship between technological competition and CSR. By focusing on top managers, we tap into the knowledge of the group of managers that are most well informed about the CSR motives of the SME. Top managers are constantly shaping the strategic direction of the company (Weaver et al. 1999) and are often directly involved in decisions on CSR (Waldman et al. 2006). Therefore, they have firsthand knowledge of the motives that drive the company's CSR policies. Third, we empirically test predictions based on this model using a unique dataset containing more than 2000 observations of top managers of large companies and SMEs. In this way, we can test whether the links between competitive environment, top managers' innovation motive and CSR hold for large as well as for small companies.

In what follows, we first discuss our conceptual framework and hypotheses. Next, we describe data and methods. Subsequently we present our empirical findings. We conclude with a discussion of our results.

\section{Conceptual Framework}

CSR refers to a concept whereby companies integrate social and environmental concerns in their business operations and in their interaction with their stakeholders on a voluntary basis (European Commission 2001). Following other studies (Weaver et al. 1999; Aguilera et al. 2007; Brown et al. 2010), we assume that engagement in CSR depends on a combination of external pressures and factors internal to the company. More specifically, we postulate that motivations of top-managers towards CSR mediate the influence of pressure from technological competition on the implementation of CSR at the company level (see Fig. 1). Below we will first argue that innovation motivation of top managers stimulates a company's engagement in CSR (H1). Next, we postulate that innovation motivation is more likely to arise if a 
company faces intensive technological competition on its output market $(\mathrm{H} 2)$. Third, we present the mediation hypothesis (H3).

\subsection{Innovation Motivation of Top Managers and CSR}

In the CSR literature different motives for CSR have been distinguished. One of the most important strategic benefits of CSR is that it may enhance the company's reputation (Surroca et al. 2010) and help to receive or maintain a licence to operate from society. In their study of corporate motives for CSR, Brønn and Vidaver-Cohen (2009) find that improving the company's image ranks first among 16 motives. Managers may also be motivated for CSR because they see it as being able to help them differentiating their company from competitors, and in this way strengthen their competitive position. Furthermore, CSR can be seen as increasing the commitment of employees and helping firms to attract talented new employees (Jones et al. 2014; Albinger and Freeman 2000). Finally, a strategic motive for CSR can be that it helps firms in avoiding regulatory intervention, meeting existing regulations and preventing costly lawsuits started against firms which apply inadequate standards for their suppliers and vendors (Carroll and Shabana 2010).

However, so far no research has focused on innovation as a motive for CSR. This is surprising, as CSR has been claimed to stimulate innovation, for several reasons. First, CSR helps in attracting highly qualified employees who may foster innovation (Clausen and Loew 2009). Turban and Greening (1997) argue that CSR will enable companies to attract more intelligent, motivated, experienced, visionary, creative, and committed employees, and this will likely also foster the innovative capability of the firm. Second, Surroca et al. (2010) argue that the innovative capacity of a firm is enhanced by the quality of the relational capital of a company. Since building team morale by good relationships among employees is an important social dimension of CSR (Mandl and Dorr 2007), CSR will strengthen the affective commitment and knowledge sharing behavior of current employees, which in turn is a determinant of innovative performance (Thomson and Heron 2006). Third, the stakeholder orientation dimension of CSR may stimulate innovation by making the company more sensitive to industrial and societal needs (Midtun 2007; Bocquet et al. 2011). Fourth, Flammer and Kacperczyk (2016) defend the CSR-innovation link by arguing that stakeholder orientation is likely to relieve customers and employees from short-termism. Long-term orientation will stimulate customers to be more loyal to the firm and tolerate failures from new products and encourage employees to invest more effort in risky innovation. Fifth, Jamali et al. (2011) show that companies that have strategic CSR partnerships with NGOs can be more capable of innovation (dependent on the social capital of the partnership). More directly, engaging in CSR may stimulate a company to perform innovations that are necessary to accomplish certain aspects of CSR (McWilliams and Siegel 2000; Clausen and Loew 2009; Surroca et al. 2010). For example, the adoption of an environmental program may stimulate product innovation of environmentally friendly products or process innovation by redesigning production processes to realize CSR related goals (e.g., reduction of energy consumption). 
Given these positive effects of CSR on innovation, we expect that top managers might be aware that CSR stimulates innovation. In the view of the theory of reasoned actions (Ajzen 1991), this belief provides the cognitive foundation of their CSR motivation. Moreover, according to expectancy theory the motivation to engage in a particular action is the product of the belief that the action will lead to a certain outcome and the value of that outcome to the decision maker (Vroom 1964). Predictions of this theory have generally received support in management research (Yang et al. 2018). As the motivation of the top manager is an antecedent to his/her behavior (Treviño et al. 2006), it is reasonable to expect that the top manager's innovation motive towards CSR will translate into a stronger engagement of the company in CSR. This seems particularly relevant for SMEs. Top managers of SMEs are constantly shaping the strategic direction of the company (Weaver et al. 1999). They are often directly involved in decisions on CSR and can dramatically change the CSR strategy of the firm (Waldman et al. 2006). Since they occupy leadership positions, their value-laden decisions are observed and interpreted by subordinates, and this will also influence the subordinates' beliefs and behavior (Kim et al. 2017). Hence, we propose the following hypothesis:

Hypothesis 1 The stronger the top manager's innovation motivation towards CSR, the more the firm will engage in CSR.

\subsection{Technological Competition and the Innovation Motive}

Business strategies and motivations are not developed in a vacuum, but are influenced by the environment of companies. Building on institutional literature, several studies have conceptualized CSR as resulting from a combination of external factors and factors internal to the company (Aguilera et al. 2007; Brown et al. 2010). Recent literature has started to explore the relationship between the level of competition and CSR. Fernández-Kranz and Santaló (2010) found that more competition in the marketplace leads to better CSR outcomes, and they conclude that CSR is used strategically by profit-maximizing firms. Empirical findings by Flammer (2015) also point into the direction of a positive relationship between the level of competition and CSR.

Firms can compete in many different dimensions, like price, distribution channels, supplier inputs, and technology (Vickers 1995; Shapiro 1989). We focus here on technological competition as previous research by Graafland and Smid (2015) showed that this type of competition stimulates CSR. In this paper, we argue that the intensity of technological competition has a positive but indirect influence on CSR, through the innovation motivation of top managers to engage in CSR. In markets where technological competition plays an important role, achieving sustainable competitive advantage depends on the innovativeness of a company (Humphreys et al. 2005). Consequently, senior managers will particularly pay attention to business strategies that encourage the innovativeness of their company (Cottam et al. 2001). 
The influence of the competitive environment on business strategies works through the perceptions of top managers, in general (Tang 2006) and also for SMEs (De Jong 2011). Top managers of companies that operate in a highly innovative business environment, will particularly value strategies that strengthen the innovative capability of their firm, because these are crucial for the firm's profitability and continuity. In terms of expectancy theory this means that, at a given level of the perception or belief that CSR leads to innovation, operating in an environment with more intense technological competition will increase the value attributed to innovation, and hence the motivation to engage in CSR will be stronger. We therefore propose the following hypothesis:

Hypothesis 2 The intensity of technological competition increases a top manager's motivation to engage in CSR because of its innovation enhancing effects.

\subsection{Mediation}

The argumentation and hypotheses developed above imply that we theorize the relationship between technological competition and firms' engagement in CSR to be mediated by the innovation motivation of top managers. Mediation analysis permits examination of processes and gives insight into how an independent variable exerts an effect on the dependent variable. Most explanations of behavior rely, whether implicitly or explicitly, on some attribution of motive to actors (Jones et al. 2014). In our framework, we have argued that technological competition increases the innovation motive of top managers towards CSR. Since the innovation motive of top managers is an important driver of CSR, this motivation is likely to mediate the relationship between technological competition and CSR of firms. This leads to our third hypothesis:

Hypothesis 3 A top manager's motivation to engage in CSR because of its innovation enhancing effects mediates the effect of the intensity of technological competition on CSR.

\section{Methodology}

\subsection{Method of Data Collection}

We collected data with a large online survey that targeted mostly SMEs and was set out in twelve European countries (Austria, Denmark, Finland, France, Germany, Hungary, Italy, Poland, Spain, Sweden, The Netherlands, UK). Before doing the survey, we discussed the questionnaire in two rounds with a group of 14 CSR and environmental experts from the twelve European countries where the survey was set out. The survey was also specifically discussed with a CSR consultant for SMEs to further test its fit 
with the SME context. Next, we pre-tested the survey by interviewing ten top managers from SMEs, in order to check whether they fully understood the survey questions and whether the questions and cut-off values fitted the context of the enterprises.

As the use of English-language questionnaires in cross-national surveys might subconsciously adjust the responses (Harzing 2005), the survey was subsequently translated into the national languages of the countries included in the study by experts. In 2011 the survey was sent to 365,002 enterprises. The e-mail addresses of the companies were obtained from KOMPASS, a global business directory company. The number of enterprises that responded to the survey was 13,637 (response percentage $3.7 \%$ ). This relatively low response rate can be attributed to the fact that completing the survey required substantial effort on the part of the SME and that the survey was conducted electronically.

We selected for this study the responses that were filled out by the top manager of the company. 2579 responses from top managers of companies were useable for our research. Using Cochran's sample size formula, we find that this response is adequate for inferring reliable conclusions for the total population of companies in the twelve countries, using an alpha of 0.05 and margin of error of $3 \%$ (Bartlett et al. 2001). ${ }^{1}$

\subsection{Measurement of Independent and Dependent Variables}

The responses to all survey questions were administered on a Likert scale ranging from 'not at all' (1) to 'very much' (7), unless indicated otherwise. Following Graafland and Smid (2015), we measured technological competition by a question on the intensity of technological competition in the market for the company's main product or service. In order to check the reliability of the measurement of technological competition, we used data for innovation in 19 sectors, measured by aggregating the outcomes of two survey questions on process and product innovation for all companies per sector. ${ }^{2}$ At the sectoral level, the bivariate correlation coefficient between the average of process and product innovation and the intensity of technological competition is $0.78(p<0.001)$, which is in line with our expectation and provides confidence in our measurement. Multiple regression analysis (controlling for control variables) showed that the intensity of technological competition at the firm level is also significantly related to the average innovation in the sector in which the company operates (estimated coefficient is $0.081 ; p<0.001$ ).

Motivation refers to the internal state of the manager, and self-reporting is an appropriate way to tap into this internal state (O’Mahoney 2013). We measured the

\footnotetext{
${ }^{1}$ Using an online calculator (https://www.surveymonkey.com/mp/sample-size-calculator/), the sample should be at least 1068 [given that the total number of companies in the twelve countries equals 16,091,476 (EU, http://ec.europa.eu/enterprise/policies/sme/facts-figures-analysis/performance-review/ index_en.htm\#h2-1)].

2 Innovation is measured by the average score on two survey questions: (1) Has your enterprise introduced new or significantly improved products or services since 2007? (Exclude the simple resale of new goods and changes of a solely aesthetic nature.); (2) Has your enterprise introduced new or significantly improved production or organizational processes since 2007? The responses to both survey questions were administered on a Likert scale ranging from 'not at all' (1) to 'very much' (7).
} 
top manager's innovation motivation by two survey questions. The first question gauges the respondents' beliefs regarding the effect of CSR on innovation by their agreement with the statement "CSR improves innovative capacity," as beliefs are an important antecedent of motivation. The second survey question measured innovation motivation more directly by asking the respondent's agreement with the statement "CSR leads to innovation" in response to the question "How important are the following motives for your enterprise to engage in CSR?"

CSR was operationalized by eight process measures indicating the efforts of companies to improve social and environmental performance. Environmental efforts were measured by four survey questions measuring concrete actions to reduce energy consumption, water consumption and waste disposal, and to improve environmental performance of suppliers. Social efforts were measured by four survey questions measuring efforts to improve the work-life balance of employees, employee training, labor conditions of suppliers and respect of human rights, and employee health by reducing work place accidents and worker's absence rate. For each issue, we used a three points scale ranging from 0 (no effort), 0.5 (incidental effort) to 1 (continuous effort).

\subsection{Controls}

We control for various external factors, company characteristics, and respondent characteristics that may drive the correlations between the dependent and independent variables (for details of the measurement of each control variable, see the footnotes of Table 3 ).

First, we control for the four other types of motivations for CSR: to increase personal satisfaction of employees; to meet customers' demands; to limit reputational risks; and to meet (future) government regulation (Surroca et al. 2010; Brammer et al. 2012). These motivations were measured in the same way as the innovation motive for CSR (see Table 2). As external factors we include sector dummies, country dummies, position in the production chain, market position, and intensity of price competition. We distinguish 19 sectors based on the National Accounts. The country in which the company operates is included as CSR is affected by the institutional environment of the company (Matten and Moon 2008). Furthermore, companies that operate in business-to-consumer (B2C) relations rather than business-tobusiness (B2B) relations are more sensitive to public reputation (Brown et al. 2010), hence we control for this. Finally, we control for the market position (distinguishing between market leader, following market leader, level playing field, and niche market), and for intensity of price competition. The more competitive the market environment, the lower profitability and, according to slack resource theory (Waddock and Graves 1997), the less resources a company has available for investing in CSR and innovation.

At the company level, we control for company size (measured by number of employees in FTEs), skill structure and age structure, as these variables have been shown to influence managerial beliefs, values, opinions, and actions (Marginson and Mcaulay 2008). Finally, we controlled for the age of the respondent. 


\subsection{Estimation Model and Estimation Technique}

In order to test if technological competition stimulates innovation motivation more than other CSR motivations, we also tested its influence on the other four types of CSR motivation. The estimation model thus consists of the following equations:

$$
\begin{gathered}
\mathrm{CSR}_{\mathrm{k}}=\sum \alpha_{\mathrm{j}, \mathrm{k}} \operatorname{Mot}_{\mathrm{j}}+\beta_{\mathrm{k}} \mathrm{TC}+\sum \gamma_{\mathrm{i}, \mathrm{k}} \mathrm{X}_{\mathrm{i}}+\mathrm{r}_{\mathrm{k}} ; \mathrm{k}=\mathrm{e}, \mathrm{s} ; \mathrm{j}=\mathrm{inn}, \text { rep, cus, emp, reg } \\
\mathrm{Mot}_{\mathrm{j}}=\beta_{\mathrm{j}} \mathrm{TC}+\sum \gamma_{\mathrm{i}, \mathrm{j}} \mathrm{X}_{\mathrm{i}}+\mathrm{r}_{\mathrm{j}} \mathrm{j}=\text { inn, rep, cus, emp, reg }
\end{gathered}
$$

Equation (1) is estimated for two dimensions of CSR ( $\mathrm{e}=$ environmental, $\mathrm{s}=$ social). Equation (2) is estimated for five motives for CSR (inn =innovation, rep=reputation, cus $=$ customers, emp $=$ employees, reg $=$ regulation). $\mathrm{TC}$ denotes the intensity of technological competition, $X_{i}$ the list of $i$ control variables and $r$ the residuals.

Substitution of Eq. (2) into Eq. (1) gives:

$$
\mathrm{CSR}_{\mathrm{k}}=\left(\sum \alpha_{\mathrm{j}, \mathrm{k}} \times \beta_{\mathrm{j}}+\beta_{\mathrm{k}}\right) \mathrm{TC}+\sum \eta_{\mathrm{i}, \mathrm{k}} \mathrm{X}_{\mathrm{i}}+\mathrm{r}_{\mathrm{k}^{\prime}}
$$

$\eta_{\mathrm{i}, \mathrm{k}}$ represent the reduced form influences of the control variables on environmental and social CSR.

In order to test the mediation hypothesis, we employed the regression-based macro for SPSS of Preacher and Hayes (2008), using 1000 bootstrap samples and bias-corrected confidence intervals. Because the mediation effect is the product of parameters $\alpha_{\mathrm{j}, \mathrm{k}} \times \beta_{\mathrm{j}}$, its sample distribution is not normal. More specifically, the sample distribution is skewed, with a shorter, fatter tail to the end of the distribution closer to zero. This implies that the lower bound of the confidence interval has less than $2.5 \%$ of the true sampling distribution, meaning that the $95 \%$ confidence interval will often improperly includes zero. The bootstrap test of Preacher and Hayes solves that problem by generating an empirical sampling distribution of the mediation effect by bootstrapping. The lower bound of the 95\% confidence is at the 2,5\% on this cumulative distribution (Zhao et al. 2010).

\section{Data Analysis}

In this section, we first present the results of factor analysis for the CSR constructs used in our regression analysis and Cronbach alphas to test the internal reliability of the five CSR motivations. Then we perform post hoc tests for common source bias and non-response bias. 
Table 1 Factor analysis of CSR

\begin{tabular}{|c|c|c|c|c|}
\hline \multirow[t]{2}{*}{ Variables } & \multirow[t]{2}{*}{ Mean } & \multirow[t]{2}{*}{ SD } & \multicolumn{2}{|l|}{ Loadings } \\
\hline & & & $\begin{array}{l}\text { Environmental } \\
\text { CSR }\end{array}$ & Social CSR \\
\hline Effort energy consumption & 0.66 & 0.37 & 0.77 & \\
\hline Effort water consumption & 0.59 & 0.40 & 0.80 & \\
\hline Effort waste disposal & 0.77 & 0.34 & 0.79 & \\
\hline Effort environmental performance suppliers & 0.49 & 0.42 & 0.68 & \\
\hline Effort work-life balance & 0.60 & 0.37 & & 0.65 \\
\hline Effort employee training & 0.74 & 0.30 & & 0.74 \\
\hline Effort health & 0.79 & 0.32 & & 0.73 \\
\hline $\begin{array}{l}\text { Effort social performance and respect human } \\
\text { rights suppliers }\end{array}$ & 0.58 & 0.42 & & 0.61 \\
\hline Eigenvalue & & & 2.96 & 1.32 \\
\hline Variance explained & & & $37.0 \%$ & $16.5 \%$ \\
\hline Cronbach alpha $(\alpha)$ & & & 0.76 & 0.62 \\
\hline
\end{tabular}

Extraction method: principal component analysis; rotation method: Oblimin with Kaiser normalization. The Kaiser-Meyer-Olkin (KMO) indicator equals 0.788 and the $p$ value of Bartlett's test of sphericity is 0.000

\subsection{Factor Analysis}

In order to ascertain the validity of the construct of CSR, we used Principle Component Analysis (with Oblimin rotation). We found two different factors reflecting environmental and social CSR (see Table 1). The factor loadings for all individual variables exceed 0.50, which can be considered very significant (Hair et al. 1998). In the regression analysis, we will use these two factors as measures of CSR. The Cronbach's alphas $(\alpha)$ confirm the internal consistency of the two CSR factors.

Table 2 reports Cronbach alphas for the five CSR motivations (innovation, reputation, customer, employee satisfaction, regulation). All except that for customer motivation meet the accepted threshold of 0.60 (Hair et al. 1998). The inter-item correlation for customer motivation is, however, equal to $0.395(p<0.001)$, which fits the optimal range for internal reliability of 0.20-0.40 (Briggs and Cheek 1986), indicating that the customer motivation measure is also internally reliable. In the regression analysis, we measure motivations by averaging the response to the two survey questions per type of motive.

From Table 2 it can also be concluded that top managers believe that CSR enhances the innovative capability of their firm and that the innovation motive is an important motive for them to engage in CSR. When we compare the average score for the innovation motive for CSR with the average scores for the other motives, the innovation motive is rated as the second-most important motive, after providing personal satisfaction to the employees of the company. Test results showed that the 
Table 2 Internal reliability of CSR motives

\begin{tabular}{llll}
\hline Motives & Measures & Mean & SD \\
\hline Innovation $(\alpha=0.79)$ & CSR improves innovative capacity $^{\mathrm{a}}$ & 4.19 & 1.71 \\
& CSR leads to innovation $^{\mathrm{b}}$ & 4.68 & 1.60 \\
Reputation $(\alpha=0.78)$ & CSR limits reputational risks $^{\mathrm{a}}$ & 4.34 & 1.70 \\
& CSR limits reputational risks $^{\mathrm{b}}$ & 4.50 & 1.63 \\
Customer $(\alpha=0.56)$ & CSR increases turnover $^{\mathrm{a}}$ & 3.13 & 1.66 \\
& Large customers ask for it $^{\mathrm{b}}$ & 3.77 & 1.89 \\
Employees $(\alpha=0.74)$ & CSR motivates the employees $^{\mathrm{a}}$ & 4.31 & 1.68 \\
& CSR creates personal satisfaction for the people in our & 5.15 & 1.41 \\
& $\quad$ enterprise $^{\mathrm{b}}$ & & \\
Regulation $(\alpha=0.78)$ & CSR helps meeting (future) government regulation $^{\mathrm{a}}$ & 3.94 & 1.69 \\
& CSR helps to meet (future) government regulation $^{\mathrm{b}}$ & 4.01 & 1.70 \\
\hline
\end{tabular}

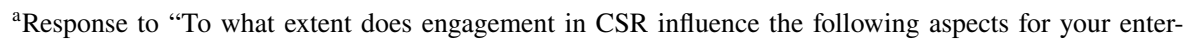
prise?"

${ }^{\mathrm{b}}$ Response to "How important are the following motives for your enterprise to engage in CSR?"

responses on the perceived effect of CSR on innovation and the innovation motive for CSR both significantly differ from 1 ('not at all') with $p$ values $<0.001$.

\subsection{Post-Hoc Test for Common Method Bias}

Before estimating the model, we considered several methodological issues. First, to address the potential concerns of common method bias, we used several remedies that are recommended by Podsakoff et al. (2003). First, in order to reduce the potential for social desirability bias, we explained in a cover letter to the respondents that the study was confidential and to be used for research purposes only. Respondents thus had little reason to present a too favorable picture, and research has shown that there are strong correlations between self-reported and actual behaviors (Beaver and Prince 2004). Second, item ambiguity was reduced by extensive pre-testing of the survey and by avoiding vague concepts and keeping the questions simple.

An ex post test for common method bias proposed by Podsakoff et al. (2003) is the marker variable technique. A marker variable is a variable that is theoretically unrelated to at least one of the variables being studied. The smallest correlation between this marker variable and the variables being studied provides a reasonable estimate of common method bias. As marker variable we selected the response to a survey question measuring the share of women in the board or executive positions in 2010. Correlating this variable to the dependent and independent variables, the 
smallest correlation was found with the reputation motive $(-0.01, p$ value $=0.58)$ and regulation motive $(-0.01, p$ value $=0.49)$. This provides evidence that our results are not plagued by common method bias.

Finally, cross-plots between dependent and the independent variables showed no heteroskedasticity, whereas box-plots indicated no problematic outliers. ${ }^{3}$ Inspecting the variance inflation factors (VIFs) (Hair et al. 1998), we found no evidence of multicollinearity.

\subsection{Post Hoc Analysis of Non-response Bias}

In order to evaluate the non-response bias, we used the Heckman two-step estimation procedure (Certo et al. 2016). The first step uses a probit model that explains the response (0 for non-response; 1 for response) in 2011. As exclusion restriction we used the degree of feeling European measured by the Eurobarometer, because the invitation letter that requested companies to respond to the survey was signed by a representative of the European Union. It is expected that respondents who feel more European, are more inclined to cooperate to the survey, independent from their interest in CSR. The estimation results of the probit model supported this proposition and showed a very significant positive effect of feeling European on the response rate $(p<0.001)$, controlling for sector, company size and the starting year of the company. From the regression result, we calculated the inverse Mills ratio, which indicates the degree that the response is influenced by unobserved characteristics of the company. By including the inverse Mill's ratio as extra control variable in the regression analysis, one removes the selection bias part from the error terms (Puhani 2000).

\section{Results}

In this section, we first report descriptive statistics. Next, we report the results of multiple regression analyses of CSR to test hypotheses 1 and 2.

\subsection{Descriptive Statistics and Correlations}

The descriptive statistics and correlations of all variables are reported in Table 3. The table shows that the independent, mediator and dependent variables are significantly related.

\footnotetext{
3 The Preacher-Hayes macro does not calculate corrections for possible heteroscedasticity. However, resampling observations using bootstrapping, as is done by this macro, is known to be asymptotically equivalent to performing the Huber-White heteroskedasticity correction.
} 
Table 3 Descriptives

\begin{tabular}{|c|c|c|c|c|c|c|}
\hline & Mean & SD & $\begin{array}{l}\text { Technological } \\
\text { competition }\end{array}$ & $\begin{array}{l}\text { Innovation } \\
\text { motivation }\end{array}$ & $\begin{array}{l}\text { Environ- } \\
\text { mental } \\
\text { CSR }\end{array}$ & Social CSR \\
\hline Technological competition & 5.24 & 1.64 & 1 & & & \\
\hline Innovation motivation & 4.50 & 1.48 & 0.07 & 1 & & \\
\hline Environmental CSR ${ }^{\mathrm{a}}$ & 0.00 & 1.00 & 0.05 & 0.25 & 1 & \\
\hline Social CSR ${ }^{\mathrm{a}}$ & 0.00 & 1.00 & 0.07 & 0.22 & 0.33 & 1 \\
\hline Austria & 0.03 & 0.16 & 0.05 & 0.04 & 0.02 & -0.02 \\
\hline Denmark & 0.06 & 0.23 & 0.09 & -0.03 & -0.08 & -0.12 \\
\hline Finland & 0.05 & 0.23 & -0.01 & -0.04 & -0.01 & 0.06 \\
\hline France & 0.09 & 0.28 & 0.07 & -0.05 & -0.04 & 0.02 \\
\hline Germany & 0.11 & 0.31 & 0.11 & 0.08 & 0.01 & -0.05 \\
\hline Hungary & 0.05 & 0.21 & 0.05 & -0.09 & 0.03 & 0.05 \\
\hline Italy & 0.31 & 0.46 & -0.18 & 0.04 & 0.03 & -0.02 \\
\hline Netherlands & 0.09 & 0.29 & -0.10 & 0.07 & -0.05 & 0.06 \\
\hline Poland & 0.06 & 0.25 & 0.06 & -0.07 & 0.02 & 0.04 \\
\hline Spain & 0.07 & 0.25 & 0.06 & 0.03 & 0.10 & 0.06 \\
\hline Sweden & 0.05 & 0.23 & -0.01 & -0.02 & -0.05 & -0.07 \\
\hline UK & 0.04 & 0.19 & -0.03 & -0.06 & 0.02 & 0.01 \\
\hline Agriculture & 0.02 & 0.14 & -0.02 & 0.00 & 0.04 & 0.01 \\
\hline Mining & 0.01 & 0.07 & 0.00 & -0.01 & 0.01 & -0.01 \\
\hline Food & 0.03 & 0.18 & 0.01 & 0.01 & 0.06 & 0.02 \\
\hline Textile & 0.03 & 0.17 & 0.01 & -0.02 & 0.00 & -0.03 \\
\hline Paper & 0.03 & 0.16 & -0.00 & 0.00 & 0.06 & -0.01 \\
\hline Oil and chemical & 0.02 & 0.15 & 0.01 & 0.03 & 0.05 & 0.01 \\
\hline Metal & 0.08 & 0.28 & 0.01 & -0.03 & 0.03 & -0.03 \\
\hline Machine & 0.09 & 0.29 & 0.02 & -0.00 & -0.02 & -0.02 \\
\hline Transport & 0.01 & 0.09 & 0.01 & -0.01 & -0.02 & 0.00 \\
\hline Other manufacture & 0.09 & 0.28 & -0.01 & -0.00 & 0.03 & -0.02 \\
\hline Utilities & 0.01 & 0.08 & -0.04 & 0.00 & 0.02 & 0.02 \\
\hline Construction & 0.07 & 0.25 & -0.05 & 0.02 & 0.01 & 0.02 \\
\hline Trade and hotels & 0.09 & 0.29 & -0.01 & -0.05 & -0.01 & -0.02 \\
\hline Transport services & 0.04 & 0.19 & -0.05 & 0.01 & 0.03 & 0.04 \\
\hline Telecom & 0.04 & 0.20 & 0.05 & 0.03 & -0.09 & 0.01 \\
\hline Finance & 0.01 & 0.07 & 0.02 & -0.04 & -0.01 & -0.01 \\
\hline Real Estate & 0.01 & 0.10 & -0.02 & 0.02 & 0.01 & -0.00 \\
\hline Other services & 0.18 & 0.38 & 0.02 & 0.00 & -0.09 & 0.03 \\
\hline Other business & 0.11 & 0.31 & -0.01 & 0.01 & 0.00 & -0.00 \\
\hline $\mathrm{B} 2 \mathrm{C}^{\mathrm{b}}$ & 1.97 & 1.05 & -0.03 & 0.02 & 0.08 & 0.04 \\
\hline Market leader & 0.13 & 0.52 & -0.04 & 0.06 & 0.01 & 0.05 \\
\hline Following market leader & 0.09 & 0.44 & 0.01 & -0.01 & 0.01 & 0.02 \\
\hline Level playing field & 0.52 & 0.52 & 0.00 & -0.04 & -0.01 & -0.01 \\
\hline Niche market & 0.26 & 0.26 & 0.02 & -0.01 & -0.04 & -0.05 \\
\hline Price competition $^{\mathrm{c}}$ & 5.06 & 1.87 & -0.02 & -0.06 & 0.03 & 0.02 \\
\hline
\end{tabular}


Table 3 (continued)

\begin{tabular}{lcccccr}
\hline & Mean & SD & $\begin{array}{l}\text { Technological } \\
\text { competition }\end{array}$ & $\begin{array}{l}\text { Innovation } \\
\text { motivation }\end{array}$ & $\begin{array}{l}\text { Environ- } \\
\text { mental } \\
\text { CSR }\end{array}$ & Social CSR \\
\hline Ln size $^{\mathrm{d}}$ & 3.08 & 1.68 & $\mathbf{0 . 0 5}$ & $\mathbf{0 . 1 1}$ & $\mathbf{0 . 1 6}$ & $\mathbf{0 . 2 3}$ \\
Low skilled & 0.33 & 0.33 & -0.04 & -0.01 & $\mathbf{0 . 0 8}$ & -0.03 \\
Medium skilled & 0.42 & 0.31 & $-\mathbf{0 . 0 5}$ & -0.03 & 0.01 & 0.02 \\
High skilled & 0.25 & 0.29 & $\mathbf{0 . 1 0}$ & 0.04 & $\mathbf{- 0 . 1 0}$ & 0.01 \\
Young & 0.11 & 0.15 & 0.02 & 0.03 & $\mathbf{0 . 0 5}$ & 0.04 \\
Medium aged & 0.66 & 0.25 & 0.01 & 0.03 & $\mathbf{0 . 0 7}$ & $\mathbf{0 . 0 9}$ \\
Old & 0.23 & 0.23 & -0.03 & $-\mathbf{0 . 0 5}$ & $\mathbf{- 0 . 1 0}$ & $-\mathbf{0 . 1 1}$ \\
Age respondent & 3.07 & 0.83 & -0.01 & 0.01 & 0.04 & $\mathbf{0 . 0 5}$ \\
Reputation motivation & 4.48 & 1.48 & 0.04 & $\mathbf{0 . 5 3}$ & $\mathbf{0 . 1 9}$ & $\mathbf{0 . 1 8}$ \\
Customer motivation & 3.48 & 1.48 & 0.05 & $\mathbf{0 . 5 1}$ & $\mathbf{0 . 1 9}$ & $\mathbf{0 . 1 5}$ \\
Employee motivation & 4.79 & 1.35 & $\mathbf{0 . 1 1}$ & $\mathbf{0 . 5 7}$ & $\mathbf{0 . 1 9}$ & $\mathbf{0 . 2 4}$ \\
Regulation motivation & 4.03 & 1.52 & $\mathbf{0 . 0 1}$ & $\mathbf{0 . 5 0}$ & $\mathbf{0 . 2 1}$ & $\mathbf{0 . 1 7}$ \\
\hline Pearson & & & & & &
\end{tabular}

Pearson correlation coefficients; italics $p<0.05$; bold $p<0.01$

${ }^{\text {a }}$ Standardized factors

${ }^{\mathrm{c}}$ Mean response to a five point scale ranging from: 'B2B'(1) to 'B2C'(5)

${ }^{c}$ Mean response to survey question 'In the market for your main product or service, your enterprise is prone to price competition,' measured on a seven point scale ranging from 'not at all'(1) to 'very much'(7)

${ }^{\mathrm{d}}$ Natural logarithm of number of employees measured in full time equivalents

${ }^{\mathrm{e}}$ Measured by four age groups $(1:<30 ; 2: 30-45 ; 3: 46-55 ; 4:>55$ years $)$

\subsection{Regression Analysis}

Before estimating the model, we standardized technological competition, the five CSR motivations and the two CSR factors.

The estimation results reported in Table 4 show that the innovation motive of the top manager stimulates the company's engagement in both environmental and social CSR. The results are robust if the sample is restricted to small businesses (number of employees in FTE $\leq 50$ ) (see columns 3 and 4). These results provide support for hypothesis 1. For environmental CSR, the innovation motive appears to be the strongest driver of CSR, compared to other motives. For social CSR, the innovation motive is the second most important motive, after the employee satisfaction motive. We also estimated Eq. (1) without the innovation motive (but with all other variables), and found that the models with innovation motive have a lower AIC than the models without innovation motive (see last row in Table 4). ${ }^{4}$ These results

\footnotetext{
4 The Akaike Information Criterion (AIC) is a criterion for model selection. It applies a penalty term for the number of parameters in the model, to correct for overfitting. The model with the lowest AIC is preferred.
} 
Table 4 Estimation results

\begin{tabular}{llll}
\multicolumn{2}{l}{ Total sample $^{\mathrm{a}}$} & \multicolumn{2}{l}{ Small companies $^{\mathrm{b}}$} \\
\cline { 3 - 4 } 1 & 2 & 3 & 4 \\
Env. CSR & Social CSR & Env. CSR & Social CSR \\
\hline
\end{tabular}

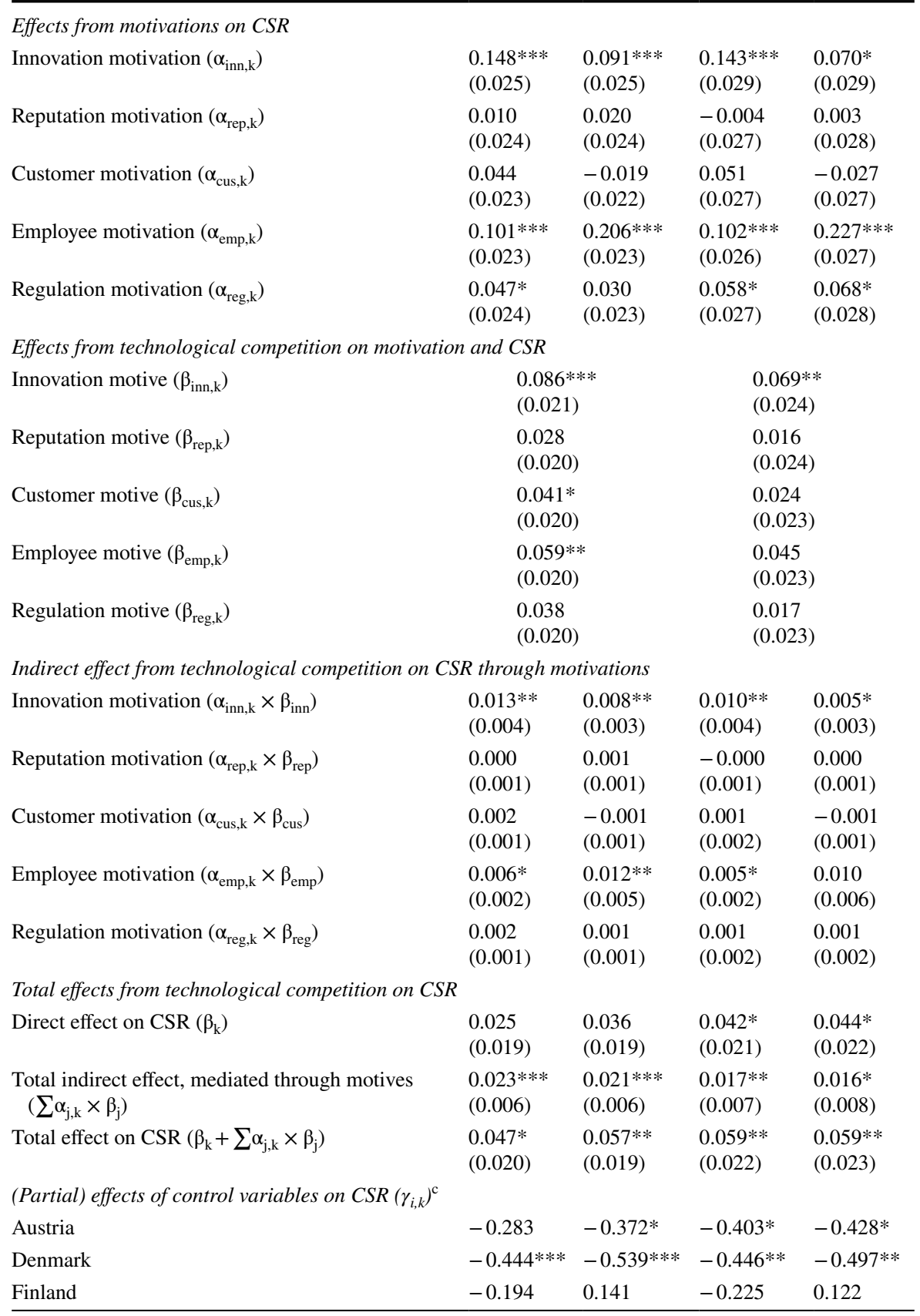


Table 4 (continued)

\begin{tabular}{|c|c|c|c|c|}
\hline & \multicolumn{2}{|c|}{ Total sample ${ }^{\mathrm{a}}$} & \multicolumn{2}{|c|}{ Small companies ${ }^{b}$} \\
\hline & 1 & 2 & 3 & 4 \\
\hline & Env. CSR & Social CSR & Env. CSR & Social CSR \\
\hline France & -0.222 & 0.054 & -0.174 & 0.136 \\
\hline Germany & $-0.251^{*}$ & $-0.355^{* *}$ & -0.218 & $-0.349 *$ \\
\hline Hungary & 0.177 & $0.386^{* *}$ & 0.221 & $0.485^{* *}$ \\
\hline Italy & -0.011 & 0.060 & 0.026 & 0.142 \\
\hline Netherlands & $-0.440 * * *$ & -0.085 & $-0.407^{*}$ & -0.157 \\
\hline Poland & 0.082 & $0.305^{*}$ & 0.165 & 0.326 \\
\hline Spain & 0.086 & -0.085 & 0.270 & 0.085 \\
\hline Sweden & -0.148 & $-0.266^{*}$ & -0.150 & -0.258 \\
\hline Agriculture & 0.049 & -0.093 & 0.116 & -0.210 \\
\hline Mining & -0.076 & -0.056 & -0.054 & -0.135 \\
\hline Food & 0.123 & -0.048 & -0.024 & -0.138 \\
\hline Textile & -0.043 & -0.090 & -0.130 & -0.214 \\
\hline Paper & $0.342^{*}$ & -0.037 & 0.273 & -0.182 \\
\hline Oil and chemical & 0.032 & -0.118 & -0.136 & -0.110 \\
\hline Metal & 0.049 & -0.068 & 0.054 & -0.060 \\
\hline Machine & $-0.224^{* *}$ & 0.000 & $-0.267^{* *}$ & 0.031 \\
\hline Transport & -0.211 & 0.064 & -0.024 & 0.259 \\
\hline Other manufacture & 0.059 & -0.079 & -0.003 & -0.134 \\
\hline Utilities & -0.093 & 0.170 & 0.047 & 0.408 \\
\hline Construction & -0.107 & 0.107 & $-0.230^{*}$ & 0.087 \\
\hline Trade and hotels & -0.054 & 0.001 & -0.011 & 0.026 \\
\hline Transport services & 0.051 & 0.177 & 0.017 & 0.181 \\
\hline Telecom & $-0.492 * * *$ & -0.067 & $-0.491 * * *$ & -0.035 \\
\hline Finance & 0.024 & -0.527 & -0.054 & -0.513 \\
\hline Real Estate & 0.106 & -0.117 & 0.025 & -0.240 \\
\hline Other services & $-0.165^{*}$ & 0.081 & $-0.200 *$ & 0.049 \\
\hline B2C & $0.042 *$ & -0.004 & 0.044 & -0.002 \\
\hline Market leader & -0.094 & -0.008 & -0.072 & -0.048 \\
\hline Following market leader & -0.063 & -0.098 & $-0.178^{*}$ & $-0.172 *$ \\
\hline Level playing field & -0.056 & -0.018 & -0.057 & -0.042 \\
\hline Price competition & -0.001 & 0.004 & 0.002 & -0.005 \\
\hline Ln size & $0.043^{* *}$ & $0.129 * * *$ & $0.047^{*}$ & $0.170^{* * *}$ \\
\hline Medium skilled & -0.041 & $0.142^{*}$ & -0.052 & 0.131 \\
\hline High skilled & -0.150 & 0.047 & $-0.203^{*}$ & 0.033 \\
\hline Young & $0.372^{* *}$ & 0.118 & $0.384 *$ & -0.044 \\
\hline
\end{tabular}


Table 4 (continued)

\begin{tabular}{|c|c|c|c|c|}
\hline & \multicolumn{2}{|c|}{ Total sample ${ }^{\mathrm{a}}$} & \multicolumn{2}{|c|}{ Small companies ${ }^{b}$} \\
\hline & 1 & 2 & 3 & 4 \\
\hline & Env. CSR & Social CSR & Env. CSR & Social CSR \\
\hline Medium aged & $0.243^{* *} *$ & 0.095 & $0.240 *$ & -0.032 \\
\hline Age respondent & $0.060 * *$ & -0.040 & 0.039 & $-0.067 *$ \\
\hline Inverse Mill's ratio & $-0.214 * *$ & -0.021 & $-0.213 *$ & -0.019 \\
\hline $\begin{array}{l}\text { Change in AIC due to inclusion of innovation } \\
\text { motive }^{\mathrm{d}}\end{array}$ & -13.85 & -3.68 & -9.58 & -0.68 \\
\hline
\end{tabular}

${ }^{\mathrm{a}}$ For the meaning of the parameter symbols, see Sect. 3.4. $\mathrm{N}=2579$. Regression using macro for SPSS of Preacher and Hayes (2008) with 1000 bootstrap samples. ${ }^{*} p<0.05$; $* * p<0.01$; $* * *<<0.001$. For the key parameters, SE are reported between brackets

${ }^{\mathrm{b}}$ Small business are defined as enterprises with 50 or less employees (in full time equivalents). $\mathrm{N}=1917$

${ }^{\mathrm{c}}$ The macro of Preacher and Hayes only presents the estimation results for the control variables of the dependent variables (environmental and social CSR), not the estimation results for the control variables for the mediators (the five CSR motives). But in the estimation of the mediators (the five CSR motives), they do control for all control variables (in line with Eq. (2) in Sect. 3.4). The estimation results for the control variables for the five CSR motives are available with the authors on request

${ }^{\mathrm{d}} \mathrm{AIC}$ is calculated as $\mathrm{n} \times \log (\mathrm{SSE} / \mathrm{n})+2(\mathrm{k}+1)$ where $\mathrm{n}=$ sample size, $S S E$ sum of squared errors, and $\mathrm{k}=$ number of predictors

demonstrate that adding the innovation motive to the other motives improves the explanatory power of the model.

Furthermore, we find that technological competition strengthens the top manager's motivation to engage in CSR because CSR improves the firm's innovative capacity, which supports hypothesis 2 . Besides innovation motivation, technological competition is also found to affect the customer and employee satisfaction motivations, but not as strong as the innovation motivation.

\subsection{Test for Mediation}

Table 4 also reports the outcomes of the regression-based macro for SPSS of Preacher and Hayes (2008) for the direct, indirect and total effects of technological competition on environmental and social CSR through motivations. The direct effects of technological competition on environmental and social CSR are insignificant. The indirect effect is equivalent to the multiplication of path a and path b in Fig. 1. Table 4 shows that the indirect effects of technological competition on environmental and social CSR mediated through innovation motivation and employee motivation are all significant, as well as the total indirect effects of all five CSR motivations together on environmental and social CSR. These results supports hypothesis 3 that innovation motivation mediates the influence of technological competition on CSR. Also the total effects (i.e., the sum of direct and indirect effects) are significant for both environmental and social CSR. 
In columns 3 and 4 Table 4 we again test the robustness of the findings on a sample of small companies. The findings for small companies are very similar to the findings for the total sample.

\section{Discussion}

\subsection{Contribution to Literature}

Our study makes several contributions. First, using a large sample of 2579 top managers of companies from twelve European countries, of which the majority are SMEs, we find that the innovation motivation of the top manager is an important determinant of firms' CSR. For environmental CSR the innovation motive is more important than any other CSR motive, for social CSR it is the second-most important driver of CSR, after the employee satisfaction motive. These findings are robust if we retest the model on a sub-sample of small companies with 50 or less employees. In previous research into the motives of CSR of SMEs (Brammer et al. 2012), no attention has been paid to the innovation motive as a driver of CSR of SMEs.

A second major contribution of our study is that we show that the strategic motivation to engage in CSR is influenced by the intensity of technological competition. Earlier studies on the influence of market competition have shown that price competition mildly reduces CSR (Graafland 2016), whereas technological competition stimulates CSR (Graafland and Smid 2015). In this study we deepen the second study by considering mediation mechanisms that can explain the positive relationship between technological competition and CSR. We find that technological competition enhances top managers' motivation to engage in CSR which in turn increases CSR. ${ }^{5}$

\subsection{Implications for Managers and Policy Makers}

Our findings are relevant to managers because the perspective that CSR stimulates innovation allows firms to incorporate CSR policies into their competitive strategy (Porter and Kramer 2006). Engagement in innovation-motivated CSR may thus be a double-edged sword: improving corporate social responsibility helps to meet society's expectations and to comply with legal requirements, while also helping the firm to become more competitive in the longer run.

For policy makers our findings are relevant because they show that stimulating CSR creates a win-win situation by simultaneously promoting innovation and therefore the long-term competitiveness of the economy. The innovation motive allows

\footnotetext{
${ }^{5}$ Besides, we found that technological competition instils CSR motivation of top managers because CSR raises the satisfaction of the firm's employees. This mechanism can be explained by the argument that creating a good working environment for employees is an important condition for realizing the innovative potential of the company (Mandl and Dorr 2007).
} 
policy makers to invoke a pro-active, strategic argument in "selling" CSR to companies, including SMEs. Our results indicate that by appealing to the innovation motive, top managers of SMEs can be more effectively induced to develop a proactive CSR strategy than by forced legal compliance. Another policy implication is that governments can stimulate CSR by economic policies that encourage technological competition, for example by funding $R \& D$ or offering tax credits to the companies for the R\&D expenditure made by those companies. Government grants to directly fund innovative activities are known to have the most impact when directed to small and medium sized enterprises. If such policies are targeted at CSR-related innovation, they encourage CSR not only directly, but also indirectly by fostering a competitive technological environment.

\subsection{Limitations and Future Research}

This research leads to several new questions that could guide future research. First, CSR is a broad area that includes many aspects of the societal dimensions of company behavior. In our paper, we focused on certain aspects of environmental and social CSR. Future research could broaden this scope by investigating the relevance of the innovation motive for other dimensions of CSR. Furthermore, as our research indicates that motives may have different relevance for environmental and social CSR, future research could elaborate on theorizing the differences in the relationship between various sets of motives and different dimensions of CSR.

Second, in this paper we focused on one specific aspect of the institutional environment of companies, the intensity of technological competition, and how this affects CSR through top manager's motivations. Future research should go beyond this starting point and analyze what kind of other institutional factors or factors internal to the company make business leaders more aware of the link between CSR and innovation and stimulate them to be more proactive in responding to CSR trends in the market.

Acknowledgements Funding was provided by Templeton World Charity Foundation, Inc.

Open Access This article is distributed under the terms of the Creative Commons Attribution 4.0 International License (http://creativecommons.org/licenses/by/4.0/), which permits unrestricted use, distribution, and reproduction in any medium, provided you give appropriate credit to the original author(s) and the source, provide a link to the Creative Commons license, and indicate if changes were made.

\section{References}

Aguilera, R., Rupp, D., Williams, C., \& Ganapathi, J. (2007). Putting the S back in corporate social responsibility: A multilevel theory of social change in organizations. Academy of Management Review, 32, 836-863.

Ajzen, I. (1991). The theory of planned behavior. Organizational Behavior and Human Decision Processes, 5, 179-211.

Albinger, H. S., \& Freeman, S. J. (2000). Corporate social performance and attractiveness as an employer to different job seeking populations. Journal of Business Ethics, 28(3), 243-253. 
Bansal, P., \& Roth, K. (2000). Why companies go green: A model of ecological responsiveness. Academy of Management Journal, 43(4), 717-736.

Bartlett, J. E., II, Kotrlik, J. W., \& Higgins, C. C. (2001). Organizational research: Determining appropriate sample size in survey research. Information Technology, Learning, and Performance Journal, 19(1), 43-50.

Battisti, M., \& Perry, M. (2011). Walking the talk? Environmental responsibility from the perspective of small-business owners. Corporate Social Responsibility and Environmental Management, 18(3), $172-185$.

Beaver, G., \& Prince, C. (2004). Management, strategy and policy in the UK small business sector: A critical review. Journal of Small Business and Enterprise Development, 11(1), 34-49.

Bocquet, R., Le Bas, C., Mothe, C., \& Poussing, N. (2011). CSR firm profiles and innovation: An empirical exploration with survey data. Working Paper WP 1117, Lyon-St Étienne: GATE.

Brammer, S., Hoejmose, S., \& Marchant, K. (2012). Environmental management in SMEs in the UK: Practices, pressures and perceived benefits. Business Strategy and the Environment, 21, 423-434.

Briggs, S. R., \& Cheek, J. M. (1986). The role of factor analysis in the development and evaluation of personality scales. Journal of Personality, 54, 106-148.

Brønn, P. S., \& Vidaver-Cohen, D. (2009). Corporate motives for social initiative: Legitimacy, sustainability or the bottom line? Journal of Business Ethics, 87, 91-109.

Brown, D. L., Vetterlein, A., \& Roemer-Mahler, A. (2010). Theorizing transnational corporations as social actors: An analysis of corporate motivations. Business and Politics, 12, 1-37.

Campbell, J. L. (2007). Why would corporations behave in socially responsible ways? An institutional theory of corporate social responsibility. Academy of Management Review, 32, 946-967.

Carroll, A. B., \& Shabana, K. M. (2010). The business case for corporate social responsibility: A review of concepts, research and practice. International Journal of Management Reviews, 12(1), 85-105.

Certo, S. T., Busenbark, J. R., Woo, H., \& Semadeni, M. (2016). Sample selection bias and Heckman models in strategic management research. Strategic Management Journal, 37(13), 2639-2657.

Clausen, J., \& Loew, T. (2009). CSR und Innovation: Literaturstudie und Befragung. Berlin: Institute 4 Sustainability.

Cottam, A., Ensor, J., \& Band, C. (2001). A benchmark study of strategic commitment to innovation. European Journal of Innovation Management, 4(2), 88-94.

De Jong, J. P. (2011). Perceived competition and innovative intentions in Dutch small and medium-sized enterprises. International Journal of Innovation Management, 15(04), 687-707.

European Commission. (2001). Promoting a European framework for corporate social responsibilities, COM 366 final, Brussels.

Fernández-Kranz, D., \& Santaló, J. (2010). When necessity becomes a virtue: The effect of product market competition on corporate social responsibility. Journal of Economics \& Management Strategy, 19(2), 453-487.

Flammer, C. (2015). Does product market competition foster corporate social responsibility? Evidence from trade liberalization. Strategic Management Journal, 36(10), 1469-1485.

Flammer, C., \& Kacperczyk, A. (2016). The impact of stakeholder orientation on innovation: Evidence from a natural experiment. Management Science, 62, 1982-2001.

Graafland, J. J. (2016). Price competition, short-termism and environmental performance. Journal of Cleaner Production, 116, 125-134.

Graafland, J. J., \& Smid, H. (2015). Competition and institutional drivers of corporate social performance. De Economist, 163(3), 303-322.

Hair, J. F., Anderson, R. E., Tatham, R. L., \& Black, W. C. (1998). Multivariate analysis. Englewood Cliffs: Prentice-Hall.

Hambrick, D. C., \& Mason, P. A. (1984). Upper echelons: The organization as a reflection of its top managers. Academy of Management Review, 9(2), 193-206.

Harzing, A. W. (2005). Does the use of English-language questionnaires in cross-national research obscure national differences? International Journal of Cross-Cultural Management, 5(2), 213-224.

Hewitt-Dundas, N. (2006). Resource and capability constraints to innovation in small and large plants. Small Business Economics, 26, 257-277.

Hull, C., \& Rothenberg, S. (2008). Firm performance: The interactions of corporate social performance with innovation and industry differentiation. Strategic Management Journal, 29(7), 781-789.

Humphreys, P., McAdam, R., \& Leckey, J. (2005). Longitudinal evaluation of innovation implementation in SMEs. European Journal of Innovation Management, 8(3), 283-304. 
Jamali, D., Yianni, M., \& Abdallah, H. (2011). Strategic partnerships, social capital and innovation: Accounting for social alliance innovation. Business Ethics: A European Review, 20(4), 375-391.

Jamali, D., Zanhour, M., \& Keshishian, T. (2009). Peculiar strengths and relational attributes of SMEs in the context of CSR. Journal of Business Ethics, 87, 355-377.

Jenkins, H. (2009). A 'business opportunity' model of corporate social responsibility for small- and medium-sized enterprises. Business Ethics: A European Review, 18, 21-36.

Jones, D. A., Willness, C. R., \& Madey, S. (2014). Why are job seekers attracted by corporate social performance? Experimental and field tests of three signal-based mechanisms. Academy of Management Journal, 57(2), 383-404.

Kim, A., Kim, Y., Han, K., Jackson, S. E., \& Ployhart, R. E. (2017). Multilevel influences on voluntary workplace green behavior: Individual differences, leader behavior, and coworker advocacy. Journal of Management, 43(5), 1335-1358.

Laufs, K., Bembom, M., \& Schwens, C. (2016). CEO characteristics and SME foreign market entry mode choice: The moderating effect of firm's geographic experience and host-country political risk. International Marketing Review, 33(2), 246-275.

Lioui, A., \& Sharma, Z. (2012). Environmental corporate social responsibility and financial performance: Disentangling direct and indirect effects. Ecological Economics, 78, 100-111.

Luo, X., \& Du, S. (2015). Exploring the relationship between corporate social responsibility and firm innovation. Marketing Letters, 26(4), 703-714.

MacGregor, S. P., \& Fontrodana, J. (2008). Exploring fit between CSR and innovation. IESE/CBS Working Paper WP-759. Barcelona: IESE.

Mandl, I., \& Dorr, A. (2007). CSR and competitiveness. European SMEs' good practice. Consolidated European Report. KMU Forschung Austria, Austrian Institute for SME Research. Retrieved May 17, 2015, from http://www.bsocial.gva.es/documents/610767/716777/CSR_competitiveness_europ ean.pdf/64db87c9-3062-4e76-bcbf-bc1bcace91b3.

Marginson, D., \& Mcaulay, L. (2008). Exploring the debate on short-termism: A theoretical and empirical analysis. Strategic Management Journal, 29, 273-292.

Matten, D., \& Moon, J. (2008). "Implicit" and "explicit" CSR: A conceptual framework for a comparative understanding of corporate social responsibility. Academy of Management Review, 33(2), 404-424.

McWilliams, A., \& Siegel, D. (2000). Corporate social responsibility and financial performance: Correlation or misspecification? Strategic Management Journal, 21, 603-609.

Midtun, A. (2007). Corporate responsibility from a resource and knowledge perspective. Towards a dynamic reinterpretation of $\mathrm{C}(\mathrm{S}) \mathrm{R}$ : Are corporate responsibility and innovation compatible or contradictory. Corporate Governance, 7(4), 401-413.

Muller, A., \& Kolk, A. (2010). Extrinsic and intrinsic drivers of corporate social performance: Evidence from foreign and domestic firms in Mexico. Journal of Management Studies, 47, 1-26.

O'Mahoney, J. (2013). Why did you do that? A methodological exploration of motive attribution. APSA 2013 annual meeting paper. SSRN: http://ssrn.com/abstract=2301459.

Padgett, R. C., \& Galan, J. I. (2009). The effect of R\&D intensity on corporate social responsibility. Journal of Business Ethics, 93, 407-418.

Podsakoff, P. M., Mackenzie, S. B., Lee, J. Y., \& Podsakoff, N. P. (2003). Common method biases in behavioral research: A critical review of the literature and recommended remedies. Journal of Applied Psychology, 88(5), 879-903.

Porter, M. E., \& Kramer, M. R. (2006). Strategy \& society: The link between competitive advantage and corporate social responsibility. Harvard Business Review, 84(12), 78-92.

Preacher, K. J., \& Hayes, A. F. (2008). Asymptotic and resampling strategies for assessing and comparing indirect effects in multiple mediator models. Behavior Research Methods, 40, 879-891.

Puhani, P. (2000). The Heckman correction for sample selection and its critique. Journal of Economic Surveys, 14(1), 53-68.

Shapiro, C. (1989). The theory of business strategy. The Rand Journal of Economics, 20(1), 125-137.

Surroca, J., Tribó, J. A., \& Waddock, S. (2010). Corporate responsibility and financial performance: The role of intangible resources. Strategic Management Journal, 31(5), 463-490.

Tang, J. (2006). Competition and innovation behavior. Research Policy, 35(1), 68-82.

Thomson, M., \& Heron, P. (2006). Relational quality and innovative performance in R\&D based science and technology firms. Human Resource Management Journal, 16(10), 28-47.

Treviño, L. K., Weaver, G. R., \& Reynolds, S. J. (2006). Behavioral ethics in organizations: A review. Journal of Management, 32, 952-990. 
Turban, D. B., \& Greening, D. W. (1997). Corporate social performance and organizational attractiveness to prospective employees. Academy of Management Journal, 40(3), 658-672.

Vickers, J. (1995). Concepts of competition. Oxford Economic Papers, 47, 1-23.

Vroom, V. H. (1964). Work and motivation. Oxford: Wiley.

Waddock, S. A., \& Graves, S. B. (1997). The corporate social performance-financial performance link. Strategic Management Journal, 18, 303-319.

Wagner, M. (2007). Integration of environmental management with other managerial functions of the firm: Empirical effects on drivers of economic performance. Long Range Planning, 40(5), 611-628.

Waldman, D. A., Siegel, D., \& Javidan, M. (2006). Components of CEO transformational leadership and corporate social responsibility. Journal of Management Studies, 43(8), 1703-1725.

Weaver, G., Treviño, L., \& Cochran, P. (1999). Corporate ethics programs as control systems, influences of executive commitment and environmental factors. Academy of Management Journal, 42, 41-57.

Welford, R., \& Frost, S. (2006). Corporate social responsibility in Asian supply chains. Corporate Social Responsibility and Environmental Management, 13(3), 166-176.

Yang, X., Wang, Y., Hu, D., \& Gao, Y. (2018). How industry peers improve your sustainable development? The role of listed firms in environmental strategies. Business Strategy and the Environment, 27(8), 1313-1333.

Zhao, X., Lynch, J. G., \& Chen, Q. (2010). Reconsidering Baron and Kenny: Myths and truths about mediation analysis. Journal of Consumer Research, 37(August), 197-206.

Ziegler, A., \& Nogareda, J. S. (2009). Environmental management systems and technological environmental innovations: Exploring the causal relationship. Research Policy, 38(5), 885-893.

Publisher's Note Springer Nature remains neutral with regard to jurisdictional claims in published maps and institutional affiliations. 